\title{
GORRESPONDENCE
}

The Editor,

\section{Fournal of Glaciology}

\section{SIR, Depth of the "frost table" on beaches in the Canadian Arctic Archipelago}

In a previous letter to the Editor (McCann and Hannell, I97 I) data were presented about the depth of the frost table on three gravel beaches in the Canadian Arctic. Their observations indicated that in the summer permanently frozen ground exists at relatively shallow depths across the intertidal zone. A further investigation of beaches north of lat. $72^{\circ}$, at widely separated sites in the Canadian Arctic, has shown similar conditions even though the beaches were characterized by varying sediment types and exposure to wave action. The observations presented here, which are summarized in Table I, are thus intended to be more widely representative of conditions throughout the eastern Archipelago.

Table I. Depth of "frost table" on beaches in the Canadian Arctic Archipelago

\begin{tabular}{|c|c|c|c|c|c|c|c|c|c|c|}
\hline Location & $\begin{array}{l}\text { Latitude } \\
\text { and } \\
\text { longitude }\end{array}$ & Date & $\begin{array}{c}\text { Mean } \\
\text { overall } \\
\text { depth } \\
\mathrm{cm}\end{array}$ & $\begin{array}{c}\text { Back } \\
\text { shore } \\
\mathrm{cm}\end{array}$ & $\begin{array}{c}\text { Storm } \\
H W M \\
\mathrm{~cm}\end{array}$ & $\begin{array}{c}H H W M \\
\mathrm{~cm}\end{array}$ & $\begin{array}{c}M H W M \\
\mathrm{~cm}\end{array}$ & $\begin{array}{c}M L W M \\
\mathrm{~cm}\end{array}$ & $\begin{array}{c}\text { Beach } \\
\text { sediment }\end{array}$ & $\begin{array}{l}\text { Mean air } \\
\text { temperature } \\
\text { during } \\
\text { observation } \\
{ }^{\circ} \mathrm{F}\left({ }^{\circ} \mathrm{C}\right)\end{array}$ \\
\hline $\begin{array}{l}\text { Northern coast } \\
\text { (Somerset } \\
\text { Island) }\end{array}$ & $\begin{array}{ll}74^{\circ} & 12^{\prime} \\
93^{\circ} & \text { I } 5^{\prime} \\
\end{array}$ & $\begin{array}{l}3,13 \\
\text { July } \\
\text { I } 972\end{array}$ & $3^{2.2}$ & 33.6 & $47 \cdot 3$ & 35.2 & 25.0 & I9.I & Gravel & $\begin{array}{l}35 \cdot 5 \\
(1.9)\end{array}$ \\
\hline $\begin{array}{l}\text { Makinson Inlet } \\
\text { (Ellesmere } \\
\text { Island) }\end{array}$ & $\begin{array}{l}77^{\circ} \mathrm{I}^{\prime} 5^{\prime} \mathrm{N} . \text {, } \\
8 \mathrm{1}^{\circ} 3 \mathrm{o}^{\prime} \mathrm{W} .\end{array}$ & $\begin{array}{l}20,27 \\
\text { July } \\
\text { 1972 }\end{array}$ & $4^{2.0}$ & 39.5 & $4^{6.4}$ & 50.1 & $47 \cdot 5$ & 26.6 & Gravel & $\begin{array}{l}37.0 \\
(2.8)\end{array}$ \\
\hline $\begin{array}{l}\text { Hooker Bay } \\
\text { (West } \\
\text { Bathurst } \\
\text { Island) }\end{array}$ & $\begin{array}{l}75^{\circ} 43^{\prime} \mathrm{N} . \text {, } \\
\text { 100 } \\
30^{\prime} \\
\text { W. }\end{array}$ & $\begin{array}{l}2-3, \text { io } \\
\text { August } \\
1972\end{array}$ & $4^{2.1}$ & 52.9 & 36.9 & $39 \cdot 1$ & $44 \cdot 3$ & 29.7 & $\begin{array}{l}\text { Fine } \\
\text { gravel }\end{array}$ & $\begin{array}{l}39.0 \\
(3.9)\end{array}$ \\
\hline $\begin{array}{l}\text { Northern coast } \\
\text { (Somerset } \\
\text { Island) }\end{array}$ & - & $\begin{array}{l}7 \\
\text { August } \\
\text { I } 973\end{array}$ & $45 \cdot 5$ & 50.0 & $4^{1} \cdot 4$ & $47 \cdot 3$ & 49.0 & 39.8 & Gravel & $\begin{array}{l}44.0 \\
(6.7)\end{array}$ \\
\hline $\begin{array}{l}\text { Radstock Bay } \\
\text { (south-west } \\
\text { Devon } \\
\text { Island) }\end{array}$ & $\begin{array}{l}74^{\circ} 43^{\prime}, \mathrm{N} ., \\
9 \mathrm{I}^{\circ} \mathrm{IO}^{\prime} \mathrm{W} .\end{array}$ & $\begin{array}{l}\text { I9, } 20 \\
\text { August } \\
\text { I972 }\end{array}$ & 30.3 & 32.0 & 30.9 & 37.9 & 30.4 & 20.2 & Gravel & $\begin{array}{l}34.0 \\
(1.1)\end{array}$ \\
\hline $\begin{array}{l}\text { Pond Inlet } \\
\text { (north Baffin } \\
\text { Island) }\end{array}$ & 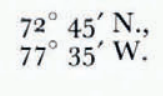 & $\begin{array}{l}28 \\
\text { August } \\
\text { I } 972\end{array}$ & 66.4 & 65.6 & 63.6 & 67.2 & 70.0 & 65.7 & Sand & $\begin{array}{l}35.6 \\
(2.0)\end{array}$ \\
\hline $\begin{array}{l}\text { Radstock Bay } \\
\text { (south-west } \\
\text { Devon } \\
\text { Island) }\end{array}$ & 一 & $\begin{array}{l}9 \\
\text { Septem- } \\
\text { ber } 1971\end{array}$ & $5^{1} \cdot 4$ & 27.0 & 50.0 & 6r.o & 6r.o & $5^{8.0}$ & Gravel & $\begin{array}{c}24.0 \\
(-4 \cdot 4)\end{array}$ \\
\hline
\end{tabular}

HHWM High high-water mark. MHWM Mean high-water mark. MLWM Mean low-water mark.

The frost-table depths were recorded by hand auger, as described previously, at a series of common points along the lines of beach profiles surveyed from the back shore to low-water mark. Between five and ten profiles were surveyed at each site, depending on local conditions, and the values recorded in columns 5-9 of Table I are thus the mean of several observations. The frost-table depths presented in column 4 are the mean of all observations taken at each site regardless of position on the beach. The data, though obtained at different times from different localities, are arranged sequentially and the seasonal pattern is evident. Early in the open-water season the frost table tends to be nearest the beach surface toward low-tide level, but at the end of the season when air temperatures have fallen below freezing the opposite applies. The greatest individual measurements of frost-table depth, over $90 \mathrm{~cm}$, were recorded on the sandy beaches at Pond Inlet in late August; elsewhere few depths greater than 
$75 \mathrm{~cm}$ were recorded. An exception to the latter occurred on the lower beach slope in late September at Radstock Bay where depths of up to $1.2 \mathrm{~m}$ were found; however, the increased depth is actually less because of the occurrence of buried lenses of frozen material less than $15.0 \mathrm{~cm}$ from the beach surface. An attempt to correlate frost-table depths with beach sediment size, and with aspect, was unsuccessful due to the considerable local variations in these controls at each site. Investigations of the changes in frost-table depths over short time intervals gave the following results: at the site on northern Somerset Island the frost table increased, across the whole foreshore, by $2.4 \mathrm{~cm}$ in the 10 day period, 3-1 3 July 1972 ; at the site on Hooker Bay the frost-table depth increased, across the whole foreshore, by $3.8 \mathrm{~cm}$ in the 8 day period 2-10 August 1972.

Geological Survey of Canada,

R. B. TAYLOR

6oI Booth Street, Ottawa,

Ontario KIA OE8, Canada

Geography Department, McMaster University, Hamilton, Ontario, Canada Io December 1973

S. B. McCann

\section{REFERENCE}

McCann, S. B., and Hannell, F. G. 1971. Depth of the "frost table" on Arctic beaches, Cornwallis and Devon Islands, N.W.T., Canada. Journal of Glaciology, Vol. 10, No. 58, p. 155-57. [Letter.]

SIR,

Microstriated ground in the Andes

The observations of Schubert (1973) in the Venezuelan Andes take me back 20 years ago, when I observed the same features in the Andes near Santiago. Although at that time I was aware of Troll's work, I had no doubt that the wind had nothing to do with it. It was a consequence of the formation of micropenitentes (very minute penitentes) in frozen soil, covered with pipkrakes at sunrise. Penitentes (Lliboutry, 1954, 1956, 1964-65, tom. I) are the consequence of an instability in the ablation process by the Sun's rays in a cold atmosphere, and follow the direction of the Sun's path, i.e. an east-west direction (which may be altered on steep slopes facing east or west).

Nothing in Schubert's article compels me to change my opinion. Even if the correlation with the direction of the wind was very good (and it is not at all the case), a simple correlation is by no means a proof. Troll's confusion came from the fact that microstriae are also seen on bare soil after gusts of wind. But they have quite different features (cf. figure in Lliboutry, 1964-65, tom. I, plate 29).

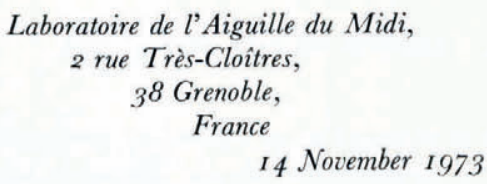

L. Lliboutry

\section{REFERENGES}

Lliboutry, L. A. 1954. The origin of penitents. Fournal of Glaciology, Vol. 2, No. I 5, p. 33 I-38.

Lliboutry, L. A. 1956. Nieves y glaciares de Chile: fundamentos de glaciologia. Santiago de Chile, Ediciones de la Universidad de Chile.

Lliboutry, L. A. 1964-65. Traité de glaciologie. Paris, Masson et Cie. 2 vols.

Schubert, C. 1973. Striated ground in the Venezuelan Andes. Fournal of Glaciology, Vol. 12, No. 66, p. $46 \mathrm{r}-68$. 